\title{
Frivilligt socialt arbete under omprövning
}

\section{TOMMY LUNDSTRÖM}

Den frivilliga sektorns roll $i$ det sociala arbetet betonas allt mer $i$ samhällsdebatten, det märks bland annat $i$ socialtjänstkommitténs nya betänkande. Det tycks vara så att frivilligsektorns roll är under ompröuning. I den här artikeln analyseras relationerna mellan det frivilligt organiserade sociala arbetet och staten. Med utgångspunkt i ett historiskt perspektiv diskuteras förutsättningarna för och konsekvenserna av att frivilligsektorn fär en mer framträdande roll $i$ produktionen av service på det sociala fältet.

\section{Inledning}

Syftet med denna artikel är att diskutera den frivilliga sektorns betydelse inom det sociala fältet och att granska förutsättningar för och konsekvenser av en expansion för sektorns produktion av tjänster och service. ${ }^{1}$ Artikeln utgår från en analys av relationerna mellan frivilligsektorn och staten från slutet av 1800-talet fram till idag. Denna analys ligger sedan till grund för en diskussion av de förändringar som sker nu.

Sedan mitten av 1980-talet och särskilt under de senaste åren märks ett ökande in-

Tommy Lundström är fil.dr. i socialt arbete och arbetar som forskare vid Sköndalsinstitutet i Stockholm. Han har forskat om socialvårdens, särskilt barnavårdens historia och arbetar nu i en forskargrupp som undersöker det frivilliga sociala arbetet i Sverige. tresse för frivilligsektorns möjligheter att bidra med alternativ, komplement och ersättning ${ }^{2}$ till den välfärdsproduktion som sker inom den offentliga sektorn. Ett exempel är socialtjänstkommitténs förslag till ny socialtjänstlag där utredarna pekar på frivillighetens potential, men även lyfter

1 Artikeln har tillkommit som en del i ett forskningsprojekt om den ideella sektorn som bedrivs i samverkan mellan Sköndalsinstitutet och Handelshögskolan, med professor Sven-Erik Sjöstrand som projektansvarig. Projektet, som inkluderar en komparativ studie av sektorns struktur och roll (under ledning av forskare från Johns Hopkins universitetet i USA), finansieras genom bidrag från HSFR, Riksbankens jubileumsfond, Civil-och Socialdepartementet.

2 För en analys av begreppsapparaten på detta område se Blennberger (1993). 
fram gränsdragningproblem i förhållande till statens och kommunernas ansvar för medborgarnas välfärd (SOU 1994:139).

Statsmakternas syn på i vilken utsträckning frivilliga insatser kan och skall ersätta eller komplettera statliga och kommunala välfärdsarrangemang skiljer sig emellertid ofta åt och framförallt är klargörande principiella ställningstaganden ovanliga. Ett exempel på en ovanligt expansionistisk linje är ett pressmeddelande med anledning av att den borgerliga regeringen hösten 1993 beslöt tillsätta en beredning vars syfte skulle vara att främja utvecklingen av den ideella sektorn, där uttryckte sig civilministern på följande vis:

Låt medborgarna ta ett större ansvar för sin närmiljö, öka valfriheten genom att släppa in frivilligorganisationer som komplement till eller ersättning för den offentliga servicen. Bryt upp onödiga gränser mellan den offentliga sektorn, den privata sektorn och den ideella sektorn (Davidson, 1993a; se även Davidson, 1993b).

Även på 1980-talet under den dåvarande socialdemokratiska regeringen uppmärksammades frivilligsektorns potential. Ett av socialdemokratins svar på krav om privatisering var att föreningar, kooperativ och folkrörelser skulle kunna komplettera den offentliga sektorn. I ett av socialberedningens betänkanden framhålls i linje med detta resonemang att det "civila samhället" och frivilligsektorn trängts undan av staten och marknadskrafterna och att föreningslivet borde ha en starkare position i det sociala arbetet (SOU 1986:19 s. 26-30). Liknande ståndpunkter märks exempelvis i den så kallade folkrörelseutredningen och i direk- tiven till denna (Regeringen 1986, SOU 1987:33-35, se även Regeringsförklaring, 1987 s. 50).

Dessa ställningstaganden kan ses som en del i en omfattande process där välfärdsstatens ideologiska och ekonomiska kris inte bara lett till privatiseringar av välfärdsarrangemang, utan även till en förändrad syn på frivilligt arbete. Dessa förändringar tycks vara relativt oberoende av om regeringen är socialdemokratisk eller borgerlig. ${ }^{3}$

Även $\mathrm{i}$ ett längre tidsperspektiv har frivilligsektorn eller folkrörelserna haft en central position i den svenska politiska diskussionen, men det har då främst handlat om organisationernas roll som intresseorganisatörer och som forum för demokratisk och social skolning. Det nya är att från mitten av 1980-talet har frivilligsektorns roll som producent av tjänster och service fokuserats. ${ }^{4}$

3 Jämför till exempel den socialdemokratiska regeringens ställningstaganden till frivilligorganisationernas plats i förnyelse av den offentliga sektorn med tankegångarna från den beredning för den ideella sektorn som tillsattes 1993 av den borgerliga regeringen (se Regeringen, 1984/85 och Civildepartementet, 1994). Den socialdemokratiska regeringen kommer att ändra direktiven till den sk ideella beredningen, men i skrivande stund (dec 1994) är dessa direktiv inte klara.

4 Service och tjänsteproduktion skall förstås $\mathrm{i}$ bred mening. Här inkluderas allt från institutionsvård till öppet-hus-verksamhet och mer eller mindre formellt stödarbete, se SOU 1993:82 för en genomgång av verksamhet som idag bedrivs inom frivilligsektorn, på det sociala fältet. 


\section{Forskningsläget}

Den frivilliga sektorns betydelse som serviceproducent har inte uppmärksammats av det svenska forskarsamhället. Det saknas inte bara teori och empiri på området, även begreppsapparaten är oklar. För sektorn som helhet finns sinsemellan delvis eller helt överlappande och mer eller mindre ideologiskt laddade begrepp, som frivillig eller ideell sektor och folkrörelser, men också internationellt inlånade termer som "nonprofit sector" och tredje sektorn (Blennberger, 1993; Lundström och Wijkström, 1995; Pestoff, 1992; SOU 1987:33).

Jag använder beteckningen den frivilliga sektorn, som tycks på väg att etableras inom socialt arbete (se SOU 1993:82). Vid sidan av frivilligsektorn finns enligt denna terminologi den statliga sektorn (i Sverige staten, landstingen och kommunerna) och marknadssektorn. Det sociala området eller socialt arbete (liksom skola, hälsovård osv) kan betraktas som fält där aktörer från de olika sektorerna uppträder. Frivilligorganisationer utmärks av att de är skilda från statsmakten, att de upprätthåller någon form av självstyre, att de inte primärt drivs i vinstsyfte, att de bildats utifrån gemensamma idéer eller intressen och att de vänder sig utåt till allmänheten (Blennberger, 1993; Gidron, Kramer, och Salamon, 1992). ${ }^{5}$

Internationellt har uppmärksammandet av sektorns roll i serviceproduktion, inte minst på det sociala området, sedan en längre tid varit större än i Sverige. Orsaken är förstås att frivilligsektorn spelar en betydande roll som serviceproducent inom exempelvis sjukvård och socialvård $\mathrm{i}$ länder som England, USA och Tyskland. Forsk- ningsmässigt manifesteras detta i studier av sektorns roll som "välfärdsproducent»: dess förhållande till stat och marknad, dess effektivitet och dess ekonomiska betydelse. På senare år märks komparativa undersökningar som söker förklara sektorns storlek och struktur med hjälp av marknadsmodeller, samt sådana som jämför institutionella och kulturella processer och historiskt-kontextuella mönster i olika länder (se Anheier och Seibel, 1990; Gidron et al, 1992, James, 1989a; Kuhnle och Selle, 1992a; Salamon och Anheier, 1994). Även i Danmark och Norge, med liknande välfärdsstatstraditioner som i Sverige, har det under senare år vuxit fram relevant forskning på området (se Klausen, 1990; Kuhnle och Selle; 1992b, c och d; Lorentzen, 1993; Selle, 1993).

När frivilligsektorn uppmärksammats $i$ svensk forskning är det, liksom i den politiska debatten, dess betydelse för intresseorganisering och dess funktion i det demokratiska systemet som fokuserats. Här märks historiskt inriktad forskning om folkrörelserna, studier av befolkningens deltagande i föreningsverksamhet och forskning som utifrån maktteorier och teorier om korporativism fokuserar organisationerna som intresseföreträdare (Blomdahl, 1990; Eng-

5 Som Kuhnle och Selle (1992d) påpekat är begreppen fält och sektor långtifrån oproblematiska. Man kan förledas att övervärdera betydelsen av att verksamhet bedrivs inom olika sektorer och underskatta likheter inom ett fält. Är det inte mer som förenar exempelvis organisatoriska former i verksamheter på det sociala fältet, vare sig de bedrivs av staten, frivilligorganisationer eller av privata företag, $i$ jämförelse med exempelvis fält som kultur och idrott? 
berg, 1986; Johansson, 1980; Lewin, 1992; Lundkvist, 1977; Petersson et al, 1989; Rothstein, 1992).

Den internationella forskningstradition som riktar in sig på serviceproduktion saknar i stor utsträckning motsvarighet i Sverige. Ett undantag är de forskare vid Sköndalsinstitutet i Stockholm som studerat det frivilliga sociala arbetet i Sverige (SOU 1993:82). ${ }^{6}$ När det gäller det frivilliga sociala arbetets historia finns en del studier av 1800-talets välgörenhetsorganisationer (se Jordansson, 1992; Press, 1994; Thullberg, 1989; Åberg, 1988). Däremot saknas undersökningar av 1900-talets frivilligorganisationer och forskning som utifrån samhällsvetenskaplig teoribildning söker sätta in sektorn i ett större sammanhang.

\section{Det frivilliga sociala arbetets historia}

\section{- Sex perioder}

En granskning av frivilligsektorns roll idag förutsätter kunskap om dess historia. Härigenom kan vi få grepp om frivilligsektorns potential som avantgarde för att utveckla det sociala arbetet, som introduktör och pådrivare av sociala reformer, som en kraft för mobilisering av utsatta grupper och som producent av socialt arbete. Men vi kan också lära oss något om frivillighetens tillkortakommanden när det gäller att implementera reformer på bred basis och att svara upp mot krav på förändringar.

6 Pestoff (1992) bedriver dock forskning kring bland annat svensk kooperation med anknytning till den internationella traditionen på området.
Analyserar man det svenska frivilliga sociala arbetets historia utifrån dess roll inom det sociala fältet, så menar jag att den kan delas in i sex mer eller mindre distinkta perioder, nämligen: välgörenhetens genombrott, den organiserade filantropin, stagnation, övertagandenas år, organisering underifrån samt ändrade förutsättningar. Varje periodisering kan förstås ifrågasättas. Detta försök, som är inspirerat av Kuhnles och Selles (1992b, c och d) forskning om Norge, utgår från relationerna mellan frivilligheten och staten, de frivilliga organisationernas roll i socialpolitiken och de orga-

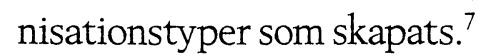

\section{Välgörenhetens genombrott- omkring 1820 till 1890}

I kritiken av den svenska välfärdsstaten märks ofta en mer eller mindre explicit föreställning om en - någonstans i historien ren och obefläckad frivillighet som övertagits, korrumperats och utarmats av en växande socialstat. Motsvarande teorier finns inom forskningen om frivilligsektorn - sär-

7 Det sociala fältet är ett begrepp som inte är särskilt precist. Här skall det förstås som socialt arbete ( $i$ vid mening) eller sådan verksamhet som kommit att bedrivas av den kommunala socialvården. Det inkluderar alltså områden som socialvård, barnavård men även hemtjänst. Jag kommer växelvis att använda begreppet det sociala fältet och socialt arbete. Periodiseringen avviker på centrala punkter från sådana som gjorts för sektorn som helhet. Där beskrivs den historiska utvecklingen ofta som en process där olika organisationstyper i vågor avlöst varandra (se Engberg, 1986; Johansson, 1980). 
skilt den amerikanska. ${ }^{8}$ Det svenska frivilliga sociala arbete som etablerades under 1800-talet motsäger, som kommer att framgå, sådana föreställningar.

De välgörenhetsorganisationer som tillkom under första hälften av 1800-talet och som hade sin storhetstid vid dess slut byggde sin verksamhet på kristna ideal och på en framväxande liberal ideologi. Särskilt under andra hälften av 1800-talet och framförallt i städerna spelade välgörenhetsorganisationerna en viktig roll inom fattigvården och för det sociala arbetet. Det var i sådana organisationer som en "modern", "vetenskaplig" eller "sann" filantropi, vars syfte var hjälp till självhjälp, växte fram. Välgörenhetsorganisationerna dominerades av kvinnor från över- och medelklassen som genom sitt engagemang gavs möjlighet till meningsfull sysselsättning i samhällsbygget (Jordansson, 1992; Åberg, 1988).

Med inspiration bland annat från det tyska Elberfeldt-systemet utgjorde, som Qvarsell (1993) och Ảberg (1988) visat, den svenska välgörenheten ett komplement till och en nära samarbetspartner med socknarnas och städernas fattigvård. Uttryckt annorlunda: välgörenhetsorganisationerna och den lokala fattigvården kan ses som ett gemensamt projekt för att komma till rätta med den fattigdom - delvis av ny typ - som var särskilt framträdande bland städernas proletariat under 1800 -talet. ${ }^{9}$ Här skulle

8 Se exempelvis Boli, 1991, för en sådan analys av Sverige.

9 För presentationer av de organisationer som tillkom under den här tiden se Jordansson, 1992; Jörgenson, 1922, Press, 1994; Thullberg, 1989; Qvarsell, 1993; Åberg, 1988. alla "goda" krafter samlas; de frivilliga, kyrkan, den kommunala fattigvården och den statliga apparaten, för att bekämpa nöden, och för att höja moralen hos det fattiga proletariatet.

Välgörenhetsorganisationerna och städernas fattigvårdsstyrelser var ofta sammanlänkade genom personliga band och mer eller mindre reglerat samarbete (Ảberg, 1988; Jordansson, 1992). Under hela 1800talet var skiljelinjerna mellan statligt reglerade och frivilliga insatser oklara. Det gäller också för de institutioner på bland annat barnavårdsområdet som byggdes upp under den här tiden (Bramstång, 1964; Ek 1938; Åman, 1976)..$^{10}$ Detta är ett viktigt faktum om man skall kunna förstå frivilligorganisationernas agerande under 1900-talet. Staten har traditionellt betraktats som vän och allierad snarare än som fiende och konkurrent. Det skall ses i ljuset av socknarnas och städernas relativt självständiga ställning gentemot den centrala statsmakten och det faktum att de lokala institutioner som hade att hantera frågorna till största delen bestod av "frivilliga" förtroendemän (Jordansson, 1992; Qvarsell, 1993).

Mot bakgrund av välgörenhetsorganisationernas moraliska mission är det intressant att notera att vänsterkritiken mot väl-

10 En källa som tydligt illustrerar detta är Fattigvården i Stockholms stad (1839), en offentlig utredning som visar att såväl när det gäller organisatorisk gränsdragning, som ekonomiska relationer för institutioner inom fattigvården, var gränserna mellan privat, offentligt och frivilligt mycket oklara. Press (1994) noterar för övrigt att redan i mitten av 1860-talet fick den betydelsefulla Allmänna skyddsföreningen stöd av Stockholms stad. 
görenheten, som ännu idag spelar en viktig roll (se Enquist, 1993; Greider, 1992), är av tidigt datum. Redan i slutet av 1870-talet utkom Strindbergs Röda rummet med sin välkända satir över välgörenhetens aktivister:

Bjuder fruntimret på frälsning? frågade snickaren/... Var har fruntimret fått den ifrån? Kanske det finns välgörenhet också; och förödmjukelse, och högfärd? /... / Ge oss arbete, om ni behagar, och lär er att betala arbetet, så behöver ni inte ränna omkring på det här sättet? (Strindberg, 1879 s. 188). ${ }^{11}$

\section{Den organiserade filantropin- omkring 1890 till 1920}

Den andra perioden startar i början av 1890-talet och sammanfaller med att Föreningen för välgörenhetens ordnande (FVO) bildas. Perioden avslutas 30 år senare då det mycket betydelsefulla Centralförbundets för socialt arbete (CSA) inflytande började minska. Det bör påpekas att tiden kring sekelskiftet sannolikt var välgörenhetens höjdpunkt. Då fanns i Stockholm enligt fattigvårdens förteckningar omkring 850 olika välgörenhetsföreningar och enskilda anstalter (Stockholms fattigvårdsnämnds protokoll, 1899-1910). ${ }^{12}$

Till de ledande organisationerna som verkade under period 2 hör FVO (bildat

11 Förlagan till Strindbergs satir var sannolikt Stockholms allmänna skyddsförening (Press, 1994).

12 Här ingick bland annat arbetsstugor för barn, ålderdomshem, fonder av olika slag, yrkesföreningar som bedrev stödverksamhet för medlemmar samt verksamheter som Röda korsets och Frälsningsarméns. Registren upprättades för att kommunens fattigvård skulle kunna hänvisa klienter till den enskilda välgörenheten.
1891) ${ }^{13}$, CSA (bildat 1903) och Svenska fattigvårdsförbundet (senare Svenska fattigvårds- och barnavårdsförbundet, bildat 1906), (Boalt et al, 1975; Boalt och Bergryd, 1974; FVO, 1989; Olsson, 1990).

En viktig faktor bakom frivilligarbetets förändring i form och innehåll kring sekelskiftet var den framväxande socialpolitiska diskursen och de ledande filantropernas ställning i denna diskurs. "Den sociala frågan« hade vid denna tid ställts på dagordningen. Det innebar att pensioner, arbetarskydd och arbetslöshetsförsäkring fick plats i den politiska diskussionen, men också att fattigvård och barnavård började ses ur ett socialpolitiskt perspektiv (Olsson, 1990; Lundström, 1986 och 1993; Ohrlander, 1992).

De tidiga välgörenhetsorganisationerna utmärktes av sina kristna och moraliska ställningstaganden ${ }^{14}$ samt av att arbetet bedrevs på icke-professionell basis, det vill säga oavlönat. De ledande sociala frivilligorganisationerna under period 2 hade sin

13 Bildandet av FVO möttes inte av någon entusiasm av den radikala pressen. I tidningen Socialdemokraten presenterades välgörenhetens representanter som sysslolösa, fåfänga och okunniga kvinnor, vilka ägnade sig åt uppgifter som kunde betraktas som konservativa eller åtminstone felriktade (se Friman et al., 1979, s. 66).

14 Det bör emellertid betonas att organisationer som Stockholms allmänna skyddsförening under senare hälften av 1800-talet lade grunden för sekelskiftets synsätt genom sin betoning av "sann filantropi", dvs sådan som byggde på individuell prövning och noggrann kontroll, till skillnad från »falsk filantropi» där givaren gav utan eftertanke, av dåligt samvete eller blödighet (Press, 1994 s. 110-111). 
idébas i mer utarbetade moderna socialpolitiska ställningstaganden, även om folkuppfostran och understödjande av "god" moral fortfarande var viktiga element i ideologin (Pauli, 1906).

Parallellt med den sociala frågans etablering började, kanske särskilt på barnavårdsområdet, formas ett mer eller mindre "vetenskapligtı tänkande i synen på avvikande beteende och på det sociala arbetets metoder, som utmanade föreställningarna hos de tidiga välgörenhetsorganisationerna. Det innebar att professionella grupper som läkarna gradvis fick ett starkare inflytande (Lundström, 1993). Tillsammans med den sociala frågans etablering, den långsamma tillväxten av en kommunal "fattigvårdsbyråkrati» och förbättrade levnadsvillkor för proletariatet, innebar detta i grunden förändrade villkor för välgörenhetsorganisationerna.

De sociala insatser som gjordes av frivilligorganisationerna kom under period 2 att i ökad omfattning bedrivas i organiserade former med anställd personal. Det gäller verksamheter som mjölkdroppen, föregångare till barnavårdscentralerna, barnavårdsbyråerna, som utövade verksamhet på barnavårdsnämndernas områden och FVO:s byrå i Stockholm, som verkade inom fattigvården (Josefsson, 1994; Qvarsell, 1993; Tiselius, 1945; Thullberg, 1989; Weiner, 1992). På detta sätt bidrog frivilligorganisationerna till att skola en expertis på det sociala området och dessutom tycks man - paradoxalt nog - ha utgjort ett avantgarde för den byråkratiserade socialvårdsverksamhet som så småningom växte fram i kommunerna.

CSA kom att spela en viktig roll som en kollektiv organisatör av den socialpolitiska diskussionen, och var själv en produkt av de liberala idéer som växte fram från 1880-talet och framåt. Organisationen fungerade som en brygga mellan filantropin och staten. Fram till 1920-talet var dess representanter mycket framgångsrika i att introducera sociala reformer (Olsson, 1990). Det kan tyckas motsägelsefullt - men framstår kanske snarare som logiskt mot bakgrund av välgörenhetsorganisationernas historia - att frivillighetens representanter blev förespråkare för reformer som innebar att den egna serviceproduktion fick läggas ned eller åtminstone att expansion försvårades.

Detta måste förstås mot bakgrund av att filantropins representanter såg sig som en del av en större rörelse mot fattigdom och dålig moral och för barnens förbättrade förhållanden - inte i första hand som representanter för en sektor. I rörelsen ingick läkare, statsbyråkrater, nämndemän i kommunernas barnavårds- och nykterhetsnämnder tillsammans med de frivilligt engagerade. ${ }^{15}$ Frivillighetens representanter satt på flera stolar samtidigt och ledande frivilligföreträdare kunde efter några år återfinnas på framskjutna poster inom statsbyråkratin. Steget mellan de ledande frivillig-

15 För ett sentida exempel, se f.d. landshövding Johan Widéns (1926) upprop "till en alla krafters samverkan för lösande av den viktiga samhällsuppgift, som ligger i en god barnavård" (a.a. s. 5) i första numret av Tidskrift för barnavård och ungdomsskydd. Den artikeln illustrerar också tydligt det svenska nämndsystemets särdrag: nämligen att exekutörerna av barnavård i själva verket genom sin position som folkvalda arbetade "frivilligt» för att verkställa statlig politik. 
organisationerna och den statliga sektorn var inte långt (Boalt och Bergryd, 1974; Lindeberg, 1983; Lundström, 1986 och 1993).

\section{Stagnation - omkring 1920 till 1940}

Att begreppet stagnation valts för period 3 betyder inte nödvändigtvis en kvantitativ tillbakagång, det vill säga att frivilligarbetet upphörde att expandera eller minskade i absoluta termer. Röda korset började till exempel bli allt mer aktivt på den nationella arenan under period 3 (Sjögreen, 1986). Trots att det saknas kunskap om den sociala frivilligsektorns kvantitativa utveckling förefaller det emellertid högst sannolikt att dess relativa betydelse minskade. Begreppet stagnation innebär i detta sammanhang emellertid framförallt att filantropins företrädare förlorade sin centrala position i den socialpolitiska debatten och att den innovativa roll de hade vid sekelskiftet minskade $i$ betydelse.

Stagnationsperioden illustreras av CSA:s utveckling. Organisationens storhetstid varade fram till 1920-talet. CSA:s minskade inflytande gäller både dess position som ideologiproducent och som centrum för initiativ till frivilligt organiserat arbete. De ledande talesmännen för sekelskiftets socialpolitiska diskurs, hamnade så småningom i konflikt med och kom att marginaliseras av representanterna för den nya socialpolitiken - socialdemokratin (Lindeberg, 1983; Lundström, 1986).

Stagnationsprocessen reflekteras tydligt i en artikel från slutet av andra världskriget av GH von Koch (1944), en ledande företrädare för CSA. Med anknytning till sekelskif- tets tänkesätt framhöll han frivilliginsatsernas omätliga värde och betydelse för folkuppfostran. De landvinningar han beskrev härrörde emellertid främst från filantropins storhetstid fram till sekelskiftet.

\section{4. Övertagandenas år- omkring 1940 till 1960}

Den svenska välfärdsstatens ideologiska genombrott sker på 1930-talet i samband med depressionen och den parlamentariska alliansen mellan socialdemokratin och bondeförbundet. Ser man till reformer som faktiskt genomfördes finner man att det var först under efterkrigstiden som uppbygget av välfärdsstaten påbörjades (Elmér, 1989). Det är mot bakgrund av den framväxande välfärdsstaten som statsövertaganden av frivilligverksamheter inom kärnområden som skola och det sociala fältet skall ses. Det bör för övrigt understrykas att statsövertaganden rör just vissa verksamheter inom vissa fält. Politikens inriktning inom exempelvis fritidssektorn, ungdomsområdet och vuxenutbildningen var i stället att via statsbidrag till föreningar uppmuntra frivilligverksamhet (Olson, 1992; Richardson, 1990; SOU 1967:19).

På det sociala fältet kan övertagandena sägas ha motiverats av två skäl. Det första kan benämnas övertagande för att uppnå "generellitet", det andra övertagande som modernisering. Övertagande för att uppnå generellitet handlar framförallt om de sociala nyttigheternas tillgänglighet. Det innebär att nyttigheterna blir en del av den generella välfärdspolitiken och därmed tillgängliga på lika villkor (eller åtminstone mer lika villkor) för personer med lika behov. Övertagande som modernisering hänför sig till 
nyttigheternas kvalitet, där modernisering innebär att de anpassas till institutionaliserade föreställningar om $»$ tidens krav«.

Ett exempel på övertagande för att uppnå generellitet rör det som i mitten av 1940-talet benämndes den sociala hemtjänsten. Redan på 1920-talet hade organisationer som Röda korset, Svenska husmodersföreningen och Svenska fattigvårdsoch barnavårdsförbundet startat hemtjänstverksamhet. Föreningarna anställde hemvårdare som utförde hushållsarbete i familjer där modern tillfälligtvis inte kunde sköta hemmet. ${ }^{16}$ Frivilligorganisationerna samarbetade ofta med kommunerna som också bidrog ekonomiskt. I början av 1940-talet tillsattes, delvis på initiativ från de organisationer som deltog med frivilliginsatser, en statlig utredning vars förslag ledde fram till ett statsbidragssystem riktat till kommunerna. Syftet var att öka verksamhetens tillgänglighet, men i praktiken gjorde reformen det också omöjligt för kommunerna att använda frivilligorganisationer för att utföra uppgifterna. Därmed hade de organisationer som initierade verksamheten spelat ut sin roll (Sjögreen, 1986; SOU 1943:15; SOU 1952:38; Szebehely, 1993).

Övertaganden av denna typ kan således betraktas som en del av uppbyggnaden av den generella välfärdspolitiken: verksamheten breddades för att den skulle kunna omfatta alla (eller åtminstone fler) som behövde den - inte bara de som bodde där det fanns aktiva frivilligorganisationer. Reformerna kunde därmed bli till rättigheter,

16 Begreppet hemtjänst kan särskilt i historiskt perspektiv ha olika betydelser. Här används det uteslutande för hushållsarbete i barnfamiljer. verksamheterna kunde - åtminstone idealt sett - utformas på likartat sätt och tilldelningen kunde ske enligt enhetliga regelsystem. ${ }^{17}$ Att frivillig verksamhet "förstatligades« eller rättare sagt kommunaliserades för att bli generell förekom inte endast inom socialvården - inom skolan avskaffades exempelvis de privata flickskolorna i syfte att åstadkomma lika villkor mellan könen (SOU 1981:34).

Övertagande som modernisering kan illustreras med utvecklingen inom barnhemsvården. Uppbyggnaden av barnhem $\mathrm{i}$ Sverige kom igång i slutet av 1800-talet, ofta på initiativ av frivilligorganisationer eller enskilda filantroper. I början av 1940-talet innehades nära hälften av barnhemmen av föreningar och stiftelser - femton år senare bara en fjärdedel (SOU 1942:45; Tidskrift för barnavård och ungdomsskydd nr 6 1942; s. 200; Barnavård och ungdomsskydd nr 1 1955, s. 12). År 1944 lades den utredning fram som utgjorde grunden till dessa förändringar. Man ville bland annat få bukt med vad som framstod som en oplanerad och vildvuxen barnavård. Ansvaret för planering och kontroll av barnhemsvården la-

17 Vad som skall ingå i den generella välfärdspolitiken är oklart. Ytterpunkterna är å ena sidan välfärdsarrangemang som alla medborgare får del av och som inte innehåller någon form av individuell behovsprövning och å andra sidan sådan som är riktad till vissa grupper och där tilldelningen görs efter någon typ av individuell behovsprövning (se Rothstein, 1994 s. 2527). Tilldelningen av social hemtjänst riktade sig bara till vissa grupper och prövningen var individuell. Att servicen blir generell betyder i detta fall att tjänsten skall kunna nå ut till hela gruppen behövande och att tilldelningen skall ske efter likartade regelverk. 
des på landstingen (Proposition 1945:227; SOU 1944:34).

En viktig bakomliggande orsak till att frivilligsektorns andel kom att minska var att antalet barnhemsplatser totalt sett gick ned. De barnhem som lades ned var emellertid de förenings- eller stiftelsedrivna, medan de landstingsdrivna och kommunala i själva verket fortsatte att expandera. ${ }^{18}$ Detta trots att de som i mitten av 1940-talet utredde frågan sade sig ha en positiv inställning till frivilligt drivna barnhem (Tidskrift för barnavaird och ungdomsskydd $\mathrm{nr} 6$ 1942, s. 200, nr 4 1944, s. 129; Barnavaird och ungdomsskydd nr 1 1955, s. 12).

De frivilliga barnhemmen drevs ofta av lokala organisationer i stiftelse- eller föreningsform, de var många gånger av äldre ursprung och förefaller ofta ha varit otidsenliga (Svenska fattigvårds- och barnavårdsförbundets kalender, 1939 och 1944). Det tycks med andra ord ha varit de barnhem som representerade ett gammalt fattigsverige som avvecklades. Vid en genomgång av Tidskrift för barnavaird och ungdomsskydd,$^{19}$ med historisk förankring i frivilligorganisationerna, finner man inga exempel på ifrågasättanden av de förändringar som skedde. Idealet var i stället stora, ljusa, rymliga, rena och välutrustade barnhem med välutbildad personal. Många av de äldre föreningsdrivna institutionerna tycks inte ha levt upp till de nya kraven på utrymme, rationalitet och professionalism. ${ }^{20}$

18 Så småningom kom även antalet landstingskommunala institutioner att minska radikalt i den avinstitutionalisering som inleddes under 1960-talet (SCB, 1980).

19 Eller Barnavaird och ungdomsskydd som tidskriften kallades från 1948.
Det bör framhållas att frivilligorganisationerna inte verkar ha varit motståndare till reformerna vare sig de motiverades med ökad generellitet eller modernisering, eller uttryckt annorlunda man motsatte sig inte reformerna eftersom de innebar ökad tillgänglighet av sociala nyttigheter och anpassning till tidens kvalitetskrav. Det betyder förstås inte att alla enskilda barnhemföreståndare eller alla Röda kors-kretsar upplevde förändringarna som positiva. Det mobiliserades emellertid inget organiserat motstånd mot reformerna. ${ }^{21}$ Intrycket är snarast att frivilligorganisationernas ståndpunkter ofta har sammanfallit med statens - eller något tillspetsat: Som ideologiproducenter verkade frivilligorganisationerna för att rollen som serviceproducent skulle minska.

Förändringarna inom hemtjänsten och i barnhemmens sammansättning under efterkrigstiden visar på frivilligorganisationernas oförmåga att i vissa faser mobilisera tillräckliga ekonomiska resurser och professionell kompetens för att anpassa sig till ändrade omgivningsförhållanden (Salamon, 1987). Samtidigt visar det på drag som möjligen är specifika för förhållandet mellan frivilligsektorn och staten i de skandinaviska länderna. Organisationerna tycks med

20 Inte heller propositionen eller riksdagsdebatten som föregick beslutet antyder några motsättningar i frågan (Proposition 1945:227; Första kammaren, 1945 prot. från, nr 30 s. 43 ff; Andra kammaren, prot. från, $1945 \mathrm{nr} 30 \mathrm{s.} 47 \mathrm{ff}$ ).

21 Höjer (1952 s. 454-455) noterar emellertid en viss bitterhet och ett visst missnöje från representanter för exempelvis kristna organisationer som tvingades lägga ned institutioner och som förlorade sitt inflytande inom hemhjälpen. 
andra ord ofta ha fungerat som pådrivare av statliga reformer och förhållandet mellan sektorerna kan, som Kuhnle och Selle (1992c) påpekat, analyseras i termer av frivilliga integrations- och samarbetsprocesser.

\section{Organisering underifrån- omkring 1960 till 1980}

Den femte perioden från omkring 1960 till en bit in på 1980-talet har jag valt att kalla organisering underifrån. Detta för att markera ett nytt fenomen i organisationsbildningen, nämligen klient- och handikapporganisationerna. ${ }^{22}$ Det bör påpekas att sådana organisationer i flera fall har sina rötter längre bak i tiden. Det gäller till exempel vissa handikapporganisationer och länkrörelsen, de förstnämnda med rötter i förra seklet och den sistnämnda i 1940-talet. Det förefaller däremot riktigt att tala om 1960och 1970-talet som en framgångsrik period för organisationsbildning och politiskt inflytande.

ISverige spelar handikapprörelsen en viktig roll genom att den vänder upp och ned på de maktrelationer varpå de tidiga välgörenhetsorganisationerna byggde. I handikapprörelsen är det utsatta grupper som organiserar sig själva för rätten till jämlika levnadsvillkor. Handikapporganisationerna kom att inta en negativ attityd till välgörenhet en ideologisk inställning som idag fătt för-

22 Med Engbergs (1986) terminologi utgör dessa organisationer exempel på identitetsrörelser, dvs rörelser där medlemmar förenas på grund av en gemensam identitet snarare än som bärare av en gemensam idé med implikationer för en enhetlig syn på samhället. Idérörelserna (dvs. de tidiga folkrörelserna) hade sin storhetstid fram till 1950-talet. nyad aktualitet för en del organisationer (Greider, 1992; Holgersson, 1992; Utberg, 1992; Sjöberg, 1987; Lindqvist, 1986). Vid sidan av handikapporganisationerna spelar klientrörelsen en central roll. Till den nya typen av organisationer hör även de ofta mycket specialiserade patientorganisationer, föräldraföreningar och kvinnojourer som vuxit fram under de senaste årtiondena (SOU 1993:82).

Handikapp- och klientrörelsen har anknytning till den vänsterkritik som växte fram i slutet av 1960-talet, och handikapprörelsen knyter i hög grad an till arbetarrörelsens ideologi. Den kritik man riktade och riktar mot välfärdsstaten gäller såväl brister i utsatta gruppers sociala rättigheter, som tvång och kontroll gentemot utsatta individer. Samtidigt är det uppenbart hur förhållandevis sstatsvänligaı handikapp- och klientorganisationer är, att de i många fall tycks ha utvecklat gott samarbete med stat och kommun och att de är beroende av statsstöd (Svedberg, 1993). Man kan som Sunesson (odaterad) tala om organisationer vilka "funnit olika lägen mellan kooptation och motkulturı det vill säga mellan att å ena sidan integreras i den gängse organisationskulturen och å andra sidan hävda medlemmarnas intressen och i viss mening avskilja sig och ta avstånd från de dominerande sätten att definiera utsatta grupper (a.a. s. 3).

\section{6. Ändrade förutsättningar- från 1980}

Den sjätte perioden kallar jag ändrade förutsättningar. Rubriken knyter an till den ekonomiska och ideologiska kris som välfärdsstaten är inne i och de förändringar denna kris kan tänkas innebära för relatio- 
nerna mellan frivilligsektorn och staten.

Av den hittillsvarande historiska framställningen, kan det verka som att de delar av frivilligsektorn som etablerades före 1960-talet inom det sociala fältet dött ut till följd av stagnation och övertaganden. I själva verket har, som den tidigare nämnda forskargruppen vid Sköndalsinstitutet visat, sektorn funnit nya verksamhetsområden och även lyckats behålla sin position i betydelsefulla nischer. Välfärdsstatens expansion har inte inneburit sektorns död. Inom det sociala fältet finns frivilligorganisationer med stor spännvidd och med omfattande verksamhet (SOU 1993:82). Man kan se dagens organisationer som "avlagringar" av den historiska process jag redovisat. Stockholms stadsmission och Frälsningsarmén representerar den första perioden. ${ }^{23}$ Röda korset aktiverade sitt nationella arbete i 1900-talets början. Bland de organisationer som utför socialt arbete finns också invandrarorganisationer samt klient- och självhjälpsgrupper som representerar den femte perioden (Jeppsson-Grassman, 1993; Svedberg, 1993).

I en undersökning av de 56 riksorganisationer som gör direkta sociala insatser konstaterar Svedberg (1993) att de vanligaste serviceverksamheterna är mer eller mindre informella stödinsatser, men att nära hälften av organisationerna även driver behandlingshem eller andra institutioner. Ungefär 40 procent av landets alkohol- och

23 Det är för övrigt intressant att notera att organisationer som Frälsningsarmén och Stadsmissionen, till stor befunnit sig utanför det sociala arbetets diskurs, trots att de utfört viktiga insatser narkomanvårdsinstitutioner drivs i själva verket som stiftelser eller i föreningsform (Socialstyrelsen, 1993). ${ }^{24}$ Sammantaget framträder en bild där den frivilliga sektorn på många sätt bidrar till det sociala arbetet och där omfattningen av insatser som görs av anställda och frivilligarbetande exempelvis tycks överstiga arbetstiden för de sammanlagt 13000 socionomer som arbetar i stat, landsting och kommun (Jeppsson-Grassman och Svedberg, 1993 och Svedberg, 1993).

I de få och begränsade undersökningar som gjorts framgår att det finns ett ökande och positivt intresse från kommunernas sida av frivilliginsatser. Paradoxalt nog ökar intresset samtidigt som bidragen till frivilligorganisationerna, som representerar en helt marginell del av de kommunala utgifterna på det sociala området, verkar minska. En för framtiden mycket viktig tendens tycks vara att bidrag som tidigare delats ut schablonmässigt på årsbasis för att stödja organisationernas allmänna verksamhet, numera i ökad utsträckning ges som riktade bidrag till resultatorienterade och för kommunerna direkt "nyttiga» verksamheter. Det märks emellertid en stor osäkerhet hos kommunalpolitiker och tjänstemän om hur man skall hantera relationerna till den frivilliga sektorn. Kan frivilligorganisationerna i ökad utsträckning ersätta kommunal verksamhet, genom entreprenader och köp av tjänster eller kan de bidra endast marginellt med kom-

24 Det bör betonas att sifferuppgifterna när det gäller missbrukarinstitutioner är osäkra (Bergmark och Oscarsson, 1994). Missbrukarvården tycks nu dessutom genomgå snabba förändringar, bland annat till följd av avregleringar och kärvare ekonomiskt klimat. 
plement och alternativ av huvudsakligen informell karaktär? (Isaksson, 1993; Bergmark, 1994). ${ }^{25}$

\section{Förutsättningar för och konsekvenser av frivilligarbetets expansion}

I det föregående avsnittet presenterade jag ett förslag till periodisering av förhållandet mellan det frivilliga sociala arbetet och staten. Jag har visat att sociala frivilligarbete som hör industrisamhället till och som uppstod under 1800-talets första hälft inte kan betraktas som fristående eller isolerat från fattigvården i socknarna och städerna. Det skall i stället redan från dess introduktion förstås i termer av integrations- och samarbetsprocesser med den statliga sektorn. Det existerar med andra ord inga "gyllene årı av en från staten helt och hållet fristående frivillighet. Detta faktum är centralt för förståelsen av frivilligsektorns relationer till staten under 1900-talet.

Filantropins eller välgörenhetens "storhetstid" inföll vid sekelskiftet. De nya organisationsbildningar som framträdde illustrerar att frivilligorganisationernas representanter tog på sig en ny uppgift, nämligen rollen som socialpolitiskt avantgarde. Under denna tid formades viktiga delar av villkoren för förhållandet mellan den frivilliga och statliga sektorn inom det sociala fältet. Här institutionaliserades de integrativa processer och det samarbete som etablerades under 1800-talet.

25 Se även SOU 1993:71 för förslag till uppstramning av bidragen på statlig nivå och till nya former för finansiering.
Kring sekelskiftet liksom under 1960och 1970-talet märks - på olika sätt - frivilligorganisationers potential att driva fram och själva ta initiativ till förändringar inom det sociala fältet. Vid sekelskiftet utgjorde frivilligorganisationerna en spjutspets för det byråkratiserade, expertdominerade sociala arbetet, medan de under 1960- och 1970-talet genom handikapp- och klientrörelsen bidrog med »organiseringen underifrån».

\section{Välfärdsstaten och frivilligorganisationerna}

Den period av stagnation som inträdde från 1920-talet tar sig uttryck i att de ledande filantropiska organisationerna förlorar sin starka position i de socialpolitiska diskussionerna. En viktig faktor i detta sammanhang kan antas vara den växande socialdemokratins negativa eller åtminstone misstänksamma hållning till en välgörenhet som byggde på underordningsrelationer mellan hjälpare och hjälpta och mot vilken kunde ställas arbetarrörelsens solidaritetsprinciper (se Qvarsell, 1993; Thullberg, 1989). ${ }^{26}$

De övertaganden av frivilligverksamheter som gjordes under efterkrigstiden är samtida med välfärdsstatens framväxt. De kan ses som typiska drag för en välfärdsmodell där större delen av välfärdsproduktionen sker inom den statliga sektorn. Även om de

26 Det är i sammanhanget intressant att notera att begreppet välgörenhet helt och hållet saknas i efterkrigstidens stora uppslagsverk: Svensk uppslagsbok (1955), medan begreppet har relativt framskjuten position i Nordisk familjebok (1922), där det används både för statliga och frivilliga insatser. 
svenska frivilliga sociala insatserna är långt ifrån betydelselösa, reflekteras deras (och den privata sektorns) relativt begränsade roll som serviceproducent $i$ att andelen anställda inom den svenska offentliga sektorn på hälso-, skol- och det sociala området i mitten av 1980-talet var omkring 90 procent, medan motsvarande andel för länder som Kanada och USA, var cirka 45 procent (Esping-Andersen, 1990, s. 158).

Övertagandena av frivilligverksamheter fäster sökarljuset på sektorns oförmåga att, i vissa lägen, kunna modernisera och expandera. Det kan gälla svagheter i att uppbåda tillräckliga personella och ekonomiska resurser för att genomföra reformer på generell basis och oförmåga att förnya innehållet. Från statens perspektiv kan dessa tillkortakommanden representera skäl till övertaganden. Motiven utgörs i så fall av modernisering av verksamheten eller att göra den till en del av den generella välfärdspolitiken. Metoderna kan bestå av utökad kontroll och bidragssystem som försvårar eller omöjliggör frivilligorganisationernas uppträdande på arenan.

Det går självklart att tänka sig en annan statlig strategi för att öka graden av tillgänglighet till sociala nyttigheter än den som valdes i Sverige. Man kan tänka sig att staten garanterar rättigheterna, men i större eller mindre grad överlåter produktionen till frivilligorganisationer, på sätt som är vanligt i till exempel Tyskland (Gidron, Kramer och Salamon, 1992). Fram till de senaste åren har diskussioner om en sådan strategi för produktion av sociala tjänster lyst med sin frånvaro i Sverige. Viktiga förklaringar till detta finns sannolikt i frivilligorganisationernas "statsvänlighet» och i det fak- tum att de sociala tjänsterna traditionellt producerats nära medborgarna i små relativt överblickbara kommuner (åtminstone fram till kommunsammanläggningarna på 1970-talet).

\section{Frivillighetens ideologiska förankring}

Från 1960-talet och framåt framträdde klient- handikapp- och självhjälpsorganisationer på fältet. De etablerade en ny typ av relationer mellan hjälpare och hjälpta, eller rättare man förenar de bägge rollerna, och fungerar dessutom som intresseorganisatörer av utsatta grupper. Man kan således tala om två typer av frivilligorganisationer: å ena sidan sådana som organiserar människor på grundval av en gemensam identitet, som patient, klient eller handikappad, och å andra sidan sådana som organiserar personer som vill hjälpa andra. ${ }^{27} \mathrm{De}$ förstnämnda har sin förankring i efterkrigstiden och de sistnämnda i de organisationer som etablerades på 1800 -talet.

Det betyder självfallet inte att verksamheter som Frälsningsarméns eller Stockholms stadsmissions skulle utmärkas av den moralism och paternalism som förekom bland 1800-talets organisationer. Det är tvärtom fullt möjligt att sådana traditioner lever starkare inom den kommunala socialvården. Vad tudelningen däremot betyder

27 Gränserna är inte alltigenom glasklara, en organisation som RFHL organiserar inte bara missbrukare eller före detta missbrukare utan även exempelvis professionella hjälpare och på Lewi Petrus stiftelsens institutioner arbetar inte bara professionella utan även före detta missbrukare. 
är att det blir möjligt att motivera ett engagemang för eller utökat utrymme för frivilligsektorn utifrån olika ideologiska positioner. Å ena sidan kan man knyta an till den arbetar- och folkrörelsetradition som finns nedlagd i klient- och handikapporganisationerna och å andra sidan till de traditionella humanitära värden som representeras av organisationer som Röda korset och Frälsningsarmén.

\section{Ett nytt kontrakt?}

Välfärdsstatens ideologiska och ekonomiska kris tycks på sikt kunna innebära förändrade relationer mellan den statliga och den frivilliga sektorn. Det verkar med andra ord pågå en omformulering av det implicita kontrakt som reglerat förhållandet mellan de båda parterna: från ett kontrakt där frivilligorganisationerna fått ekonomiska bidrag för att bedriva verksamhet som, utan tydliga krav på specifika resultat, förväntats gynna medborgarna $i$ allmänhet eller särskilda grupper, till ett kontrakt där frivilligorganisationerna får betalt för att leverera specificerade tjänster. Det gamla kontraktet lägger tonvikten vid organisationernas betydelse för ideologiproduktion och för demokratisk och social skolning, det nya vid organisationernas roll som producenter av tjänster.

Det vi nu bevittnar kan vara inledningen på vad som skulle kunna betecknas som en "amerikanisering" av frivilligsektorn, det vill säga en ökning av antalet professionella organisationer där medlemmar spelar en underordnad roll, för vilka verksamheten huvudsakligen utgörs av serviceproduktion och där ideologiproduktion och intresse- organisering är underordnat. Det amerikanska contracting-out systemet, det vill säga att stat och kommun lägger ut verksamhet på bland annat frivilligorganisationer, tycks $\mathrm{i}$ USA ha inneburit ökad styrning och professionalisering av organisationernas verksamhet för att de skall kunna leva upp till beställarnas krav (Smith och Lipsky, 1993).

En sådan förändring av frivilligsektorns roll skulle i Sverige innebära att organisationerna i större utsträckning tar på sig "reguljärau, mer administrativt och personellt krävande uppgifter och inte som nu huvudsakligen begränsar sig till relativt "informella" uppgifter där man kompletterar den kommunala socialvården med olika typer av stödinsatser. Det är självklart så att det finns en serie möjliga scenarier mellan det "svenskau och det "amerikanskau. Men att trycket ökar för att frivilligsektorn och »det civila samhälletu skall ta ett större ansvar för de sociala frågorna tycks vara ett faktum. Detta sannolikt oberoende av om vi har en socialdemokratisk eller borgerlig regering.

För frivilligsektorn finns olika möjligheter att anpassa sig till erbjudanden eller krav om att ta över verksamheter från stat och kommun. En möjlighet är att de nuvarande organisationerna omformar sin verksamhet $\mathrm{i}$ sådan riktning, genom att exempelvis avspjälka serviceproduktionen (i stiftelseform) från annan (medlemsstyrd) verksamhet. En annan möjlighet är att vi får se nya typer av serviceproducerande organisationer, som inte skiljer sig så mycket från privata företag, förutom att produktionen inte i första hand sker i direkt vinstintresse.

Man kan spekulera över i vilken utsträckning organisationer inom dagens frivilligsektor verkligen önskar sig, kommer att gå 
med på eller kan tvingas medverka i utökad service-produktion genom contracting-out - här finns ju potentiella hot mot organisationernas självständighet och en syn på statens ansvar som inte delas av majoriteten av frivilligorganisationerna inom det sociala fältet (Svedberg, 1993). En genomgripande ändring av "kontraktet« mellan stat och frivillighet kräver med andra ord förändringar av institutionaliserade värden som har förankring i svensk folkrörelsetradition. Service-produktion inom det sociala fältet har kommit att spela en förhållandevis marginell roll både i den socialpolitiska diskussionen och i praktiken (även om dess faktiska betydelse varit större än många trott). För många organisationer utgör i stället frivilligsektorns betydelse för demokrati, folkupplysning och inte minst intresseorganisering de positiva idealen. Till detta kommer institutionaliserade samarbetsrelationer med den statliga sektorn, där organisationerna hittills haft stor frihet och inte utsatts för särskilt mycket kontroll och styrning utifrån.

För många organisationer finns således en principiellt grundad skepsis mot att driva verksamhet som ersätter kommunal eller statlig serviceproduktion, medan man är positiv till att som hittills bidra med komplement och alternativ. Därutöver kommer frivilligorganisationernas oro över hur en ny inriktning av det ekonomiska stödet kommer att påverka deras självständighet (Bergmark, 1994). ${ }^{28}$ Det finns med andra ord

28 I linje med denna oro pekar Smith och Lipsky

(1993) på att det ökade bruket av "contractingout« inom det sociala fältet i USA inneburit ökad statlig styrning av organisationernas aktiviteter faktorer som talar för att frivilligorganisationerna kommer att försöka stå emot ökat tryck från stat och kommun. Mot detta står emellertid hoten om drastiska avrustningar av välfärdsstaten och därmed ett framtvingat ökat deltagande i serviceproduktion.

\section{Vinster med frivillighet}

Avslutningsvis några ord om frivilligsektorn och effektivitet. En huvudfråga när det gäller att föra över verksamheter till frivilligsektorn är vilka vinster som politiker och andra beslutsfattare kan förvänta sig. Principiellt kan man tänka sig två typer: Den första "vinsten« rör de speciella värden som frivilligheten kan tänkas ha i jämförelse med ett professionellt socialt arbete. Här finns välkända idéer om att genuin, »amatöristisk" medmänsklighet har ett specifikt värde som inte kan ersättas av, utan tvärtom riskerar att utplånas av den offentliga sektorns byråkrati och professionalism. Med förankring $i$ »organisering underifrån", finns dessutom tanken att de som är bäst skickade att hjälpa andra är de som lever nära de utsattas verklighet eller själva har varit drabbade av samma problem (Beckman, 1981).

Den andra vinsten som beslutsfattarna inte talar så ofta om men som förstås hela tiden finns med i bilden, är rent ekonomisk. Man kan principiellt tänka sig att frivilligsektorn kan bidra till minskade kostnader i jämförelse med den offentliga sektorn pååtminstone fem sätt: för det första genom att frivilligorganisationerna vid sidan av professionella insatser kan mobilisera oavlönat frivilligarbete, för det andra genom att de kan använda medel som insamlats genom 
gåvor, för det tredje genom att de har mindre kostnader för byråkrati, för det fjärde genom att de kan anlita billigare arbetskraft, och för det femte att stat och kommun genom. att använda entreprenader inte binder upp sig som om man själva inrättar verksamhet.

Sett ur ekonomiskt perspektiv är det endast de två första punkterna som skiljer de vinster som utkontraktering till frivilligorganisationer kan innebära jämfört med entreprenader till privata företag. Däremot tillkommer de specifika fördelar som eventuellt kan finnas i frivilligorganisationernas engagemang och som kanske kan "växlas in" i bättre behandlingsresultat. Dessutom finns tanken om en mer långsiktig effekt, nämligen att en förstärkning av frivilligsektorn och "det civila samhället» på sikt kan minska behoven av kostnadsslukande välfärdsarrangemang.

I vilken utsträckning kan sådana här föreställningar finna stöd i empiri? Är det möjligt att mobilisera ökade frivilliginsatser? Bland politiker märks ibland en föreställning om att svenska folket är jämförelsevis passivt och att det därför finns en stor potential (se Davidson, 1993b). JeppssonGrassman (1993) har i sin undersökning av svenskarnas frivilliginsatser visat att Sverige ligger i nivå med länder i Europa som brukar räknas till de främsta när det gäller frivilliginsatser. Sverige tycks visserligen skilja sig åt när det gäller vilka fält som insatserna koncentreras till (idrott snarare än sociala insat- ser), men alltså inte i omfattning. Även om många personer i Jeppsson-Grassmans undersökning säger sig vara beredda till större eller nya insatser (a.a., 1993) kan man med tanke på det redan idag stora engagemanget fråga sig hur stor potentialen är för en ökning, särskilt om insatserna rör socialt utsatta grupper.

I internationell forskning finns, även om det bör påpekas att det till stor del saknas systematisk kunskap, en viss skepsis om frivilligorganisationers förmåga att - åtminstone mer långsiktigt - bidra till kostnadsreduceringar. James (1989) pekar på att när entreprenader och köp av tjänster från organisationer ökar i omfattning och när sådana kontrakt får en viss varaktighet så tenderar avgifter och gåvor till frivilligorganisationer att minska i omfattning, professionell personal tycks ersätta frivillig arbetskraft och statliga eller kommunala standards och regelverk kommer att styra också frivilligorganisationerna (a.a., s. 7). Det förefaller således finnas en tendens till anpassning till de dominerande institutionella villkoren inom fältet och därmed anledning till en viss skepsis inför förhoppningar om stora långsiktiga ekonomiska vinster av "contracting outu. Vad beträffar förhoppningarna om att en starkare frivilligsektor och ett förstärkt civilt samhälle skall kunna innebära minskade behov av statliga välfärdsarrangemang är de nog mer ideologiskt än empiriskt grundade. 


\section{Referenser}

Andra kammaren (1945) protokoll från,.

Anheier, Helmut K och Wolfgang Seibel, red, (1990) The third Sector: Comparative Studies of Nonprofit Organizations. Berlin: De Gruyter. Barnavård och ungdomsskydd. Årgång 1948-1964. Beckman, Svante (1981) Kärlek på tjänstetid. Stockholm: Arbetslivscentrum.

Bergmark, Anders och Lars Oscarsson, (1994) "Swedish alcohol treatment in transition. Facts and fiction" i Nordisk alkoholtidskrift, vol 11, english supplement: 20-31.

Bergmark, Åke (1994) Från bidrag till ersättning. Om kommunernas stöd till de frivilliga organisationerna inom den sociala sektorn. Sköndalsinstitutets skriftserie, nr 1. Stockholm: Sköndalsinstitutet.

Blennberger, Erik (1993) „Begrepp och modeller» i SOU 1993:82.

Blomdahl, Ulf (1990) Folkrörelserna och folket, med utblick mot framtiden. Stockholm: Carlssons.

Boalt, Gunnar et al. (1975) De socialpolitiska centralförbunden. Stockholm: CSA.

Boalt, Gunnar och Bergryd, Ulla (1974) Centralförbundet för socialt arbete - ett kapitel svensk socialhistoria. Stockholm: CSA.

Boli, John (1991) Sweden: „Is there a Viable Third Sector» i Robert Wuthnow, red, Between States and Markets. The Voluntary Sector in Comparative Perspective. Princeton: Princeton University Press.

Bramstång, Gunnar (1964) Förutsättningar för barnavairdsnämnds ingripande mot asocial ung dom. Lund: Gleerups.

Civildepartementet (1994) Ideella beredningens rapport 31 mars 1994. Stockholm: Civildepartementet.

Davidson, Inger (1993a) Pressmeddelande. Stockholm: Civildepartementet, 1993-05-28.

Davidson, Inger (1993b) "Individer, folkrörelser och samhälle» i Folkrörelse- och föreningsguiden. Stockholm: Civildepartementet och Fritzes.

Ek, Gustaf(1938) Den svenska blindvärdens uppkomst. Stockholm: Oskar Eklunds.

Elmér, Åke (1989) Svensk socialpolitik. Stockholm: Liber.
Engberg, Jan (1986) Folkrörelserna i välfärdssamhället. Umeå: Statsvetenskapliga institutionen Umeå universitet.

Enquist, PO (1993) »Rätten att slippa vara tacksam" i Moderna tider nr 36, s 11-14.

Esping-Andersen (1990) The Three Worlds of Welfare Capitalism. Cambridge: Polity Press.

Fattigvården i Stockholms stad (1839) Underdånigt betänkande med dertill hörande handlingar angående fattigvården i Stockholms stad.

Friman, Helena et al. (1979) Barn i stan. Från sekelskifte till sjuttiotal. Stockholm: Folksam.

FVO (1989) FVO 100 år 1889-1989. Stockholm: FVO.

Första kammaren (1945) protokoll från,.

Gidron, Benjamin, Ralph M Kramer och Lester M Salamon, red, (1992) Government and the Third Sector. San Francisco: Jossey Bass.

Gidron, Benjamin, Ralph M Kramer och Lester M Salamon (1992) „Government and the Third Sector in Comparative Perspective: Allies or Adversaries?" i Gidron et al, red.

Greider, Göran (1992) „Moralisk elit vädrar morgonluft« i Dagens Nyheter 24/12.

Holgersson, Leif (1992) Socialtjänst, lagtexter med kommentarer i historisk belysning. Stockholm: Tidens förlag.

Höjer, Karl J (1952) Svensk socialpolitisk historia. Stockholm: Norstedts.

Isaksson, Kerstin (1993) "Socialtjänsten och frivilliga organisationer i Västerås och Gällivare» i SOU 1993:82.

James, Estelle, red, (1989a) The Nonprofit Sector in International Perspective. New York: Oxford University Press.

James, Estelle (1989b) „The Private Provision of Public Services: A Comparison of Sweden and Holland« i Estelle James, red.

James, Estelle (1989c) "Introduction" i Estelle James, red, The Nonprofit Sector in International Perspective. New York: Oxford University Press. Jeppsson-Grassman, Eva (1993) „Frivilliga insatser i Sverige - en befolkningsstudie» i SOU 1993:82.

Jeppsson-Grassman, Eva och Lars Svedberg (1993) „Frivillig verksamhet på fältet. En närstudie av 
sju organisationer« i SOU 1993:82.

Johansson, Hilding (1980) Folkrörelserna i Sverige.

Stockholm: Sober.

Jordansson, Birgitta (1992) »Hur filantropen blir en kvinna. Fattigvård och välgörenhet under 1800 talet»i Historisk tidskrift, nr 4: 468-501.

Josefsson (1994) "På barnens sida i nödens Hagalund" i SSR-tidningen $\mathrm{nr}$ 3, s 20-22.

Jörgensen, A Th (1922) Filantropins ledare och former under det nittonde århundradet. Stockholm.

Klausen, Kurt K (1990) Organisatorisk inertiog mikrodynamiske processer. Ledelsemessige og organisatoriske processer i frivillige organisationer. Köpenhamn: Samfundslitteratur.

von Koch (1944) »Det frivilliga hjälparbetets betydelse» i Alf Norbäck och Karl-Erik Keine, red,: Livssyn och socialvaird. Stockholm: Svenska tryckeriaktiebolaget.

Kuhnle, Stein och Per Selle, red, (1992a) Government and Voluntary Organizations.Aldershot: Avebury

Kuhnle, Stein och Per Selle (1992b) „The Historical Precedent for Government Nonprofit Cooperation in Norway“ i Gidron et al.

Kuhnle, Stein och Per Selle (1992c) "Governmental understanding of voluntary organizations: Policy Implications of Conceptual change in postwar Norway « i Stein Kuhnle och Per Selle, red.

Kuhnle, Stein och Per Selle (1992d) "Government and Voluntary Organizations: A Relational Perspective« i Stein Kuhnle och Per Selle, red.

Levenstam, Thorsten (1981) Kyrklig diakoni och samhällets sociala omsorgsarbete omkring 1850-1975. Stockholm: Verbum.

Lewin, Leif (1992) Samhället och de organiserade intressena. Stockholm: Norstedts.

Lindeberg, Sven-Ola (1983) CSA och arbetslöshetspolitiken. Stockholm: CSA.

Lindqvist, Bengt (1986)(Utan titel) i En seminarierapport. Handikapphistoria. Stockholm: Arbetarrörelsens arkiv.

Lorentzen, Håkon (1993) Frivillighetens integrasjon. Staten og de frivillige velferdsprodusentene. Rapport 93:10. Oslo: Institutt for samfunnsforskning.
Lundkvist, Sven (1977) Folkrörelserna i det svenska samhället 1850-1920. Stockholm: Sober.

Lundström, Tommy (1986) Arbetslösheten och socialvärden. En historisk studie 1906-1985. Stockholm: Socialhögskolan - Stockholms universitet.

Lundström, Tommy (1993) Tvångsomhändertagande av barn - en studie av lagarna, professionerna och praktiken under 1900-talet. Stockholm: Socialhögskolan -Stockholms universitet.

Lundström, Tommy och Filip Wijkström (1995) Defining the Nonprofit Sector: Sweden, Working papers of the Johns Hopkins Comparative Nonprofit Sector Project, nr 16, Baltimore: Johns Hopkins University.

Nordisk familjebok (1922), band 33 andra uppl. Stockholm: Nordisk familjeboks förlag.

Ohrlander, Kajsa (1992) I barnens och nationens intresse. Socialliberal reformpolitik 1903-1930. Stockholm: Högskolan för lärarutbildning.

Olson, Hans-Erik (1992) Staten och ungdomens fritid. Kontroll eller autonomi? Lund: Arkiv.

Olsson, Sven E (1990) Social Policy and Welfare State in Sweden. Lund: Arkiv.

Pauli, Ebba (1906) "Fattigvård och folkuppfostran" i Fattigvård och folkförsäkring, serie 2 häfte 2 . Stockholm: CSA:s fattigvårdskommitté.

Pestoff, Victor A (1992) "Third sector and Co-operative Services - an Alternative to Privatization? « i Journal of Consumer Policy, vol 1992 pp 21-45.

Petersson, Olof Anders Westholm och Göran Blomberg (1989) Medborgarnas makt. Stockholm: Carlssons.

Press, Maria (1994) „Skyddsfruar och ordningsmän - en studie i 1800-talets nytänkande filantropi« i Peteer Mark (red) Studier och handlingar rörande Stockholms historia VII. Stockholm: Stockholms stadsarkiv.

Proposition 1945:227

Qvarsell, Roger (1993) „Välgörenhet, filantropi och frivilligt socialt arbete - en historisk översikt« $i$ SOU 1993:82.

Regeringen (1986) Utredning om ett ökat ansvar för folkrörelser, föreningar och kooperativ. Dir 1987:17.

Regeringen (1993) Tillsättande av en beredning för 
främjande av den ideella sektorns utveckling. PM, Bilaga vid regeringssammanträde 1993-0527.

Regeringens skrivelse 1984/85:202 Skrivelse om den offentliga sektorns förnyelse.

Regeringsförklaring (1987)Riksdagens protokoll, 1987/88:26/1087 paragraf 3.

Richardson, Gunnar (1990) Svensk utbildningshistoria. Skola och samhälle förr och $n u$. Lund: Studentlitteratur.

Rothstein, Bo (1992) Den korporativa staten. Stockholm: Norstedts.

Rothstein, Bo (1994) Vadbör staten göra? Stockholm: SNS.

Salamon, Lester M(1987)»Partners in Public Service: The Scope and Theory of Government-Nonprofit Relations« i Walter W Powell, red, The Non Profit Sector: A Research Handbook. New Haven: Yale University Press.

Salamon, Lester M och Anheier, Helmut, K (1994) The Emerging Sector: The Nonprofit Sector in Comparative Perspective - An Overview. Baltimore: The Johns Hopkins University, Institute for Policy Studies.

SCB (1980) Samhällets barnavård 1978. SoS. Stockholm: SCB.

Selle, Per (1993) "Voluntary Organizations and the Welfare State: the Case of Norway i i Voluntas, vol $4 \mathrm{nr} 1$.

Sjögreen, Gunilla (1986) Frivilliga förr - Röda korsets roll i Sverige 1918-2000. Stockholm: Röda korset.

Smith, Steven Rathgeb och Michael Lipsky (1993) Nonprofits for Hire. The Welfare state in the Age of Contracting. Cambridge: Harvard University Press.

Socialstyrelsen (1993) Missbrukarvaird till rätt pris? 1993:7. Stockholm: Socialstyrelsen.

SOU 1942:45 Statistisk undersökning angående barnhemmen.

SOU 1943:15 Statsbidrag till social hemhjälpsverksamhet.

SOU 1944:34 Utredning och förslag angående revision av lagstiftningen om barnavairdsanstalter och fosterbarnsvård.

SOU 1952:38 Hemhjälp.
SOU 1963:47 Åldringsvårdens läge.

SOU 1967:19 Statens stöd till ungdomsverksamhet.

SOU 1981:34 Fristående skolor för skolpliktiga elever

SOU 1986:19 Aktuella socialtjänstfrågor.

SOU 1987:33 Ju mer vi är tillsammans

SOU 1993:71 Organisationernas bidrag.

SOU 1993:82 Frivilligt socialt arbete. Kartläggning och kunskapsöversikt.

SOU 1994:139 Ny socialtjänstlag.

Stockholms fattigvairdsnämnds protokoll (18991910) Fvn:s protokoll, sekreterarexpeditionen: Handlingar rörande välgörenhetsföreningar och enskilda anstalter (otryckt: Stockholms stadsarkiv).

Strindberg, August (1879) Röda rummet. Stockholm: Bonniers, 1974.

Sunesson, Sune (odaterad) Kooptation eller motoffentlighet. Strategier för de förtrycktas organisering. Stencil. Lund: Institutionen för socialt arbete.

Svedberg, Lars (1993) "Socialt in riktade frivilligorganisationer. Några grundläggande karaktäristika« i SOU 1993:82.

Svensk uppslagsbok (1955) band 31 andra uppl. Malmö: Förlagshuset Norden.

Svenska fattigvårds- och barnavårdsförbundets kalender (1939 och 1944) Stockholm: Norstedts.

Szebehely, Marta (1993) Hemvairdarinna i barnfamilj och hemhjälp àt gamla - kvinnovänliga reformer? Opublicerad uppsats. Stockholm: Socialhögskolan - Stockholms universitet.

Thullberg, Per (1989) „Föreningen för Välgörenhetens Ordnande bildades 1889« i FVO.

Tidskrift för barnavård och ungdomsskydd. Årgång 1926-1947.

Tiselius, Ellen (1945) „Barnavårdsbyrån i Stockholm 1908-1944" i Tidskrift för barnavård och ungdomsskydd, $\mathrm{nr}$ 4: 113-120.

Utberg, Rolf (1992) „Handikapprörelsen« i Nationalencyklopedin. Höganäs: Bra böcker.

Weiner, Gena (1992) »De »olydiga« mödrarna. Konflikter om spädbarnsvård på en Mjölkdroppe« i Historisk tidskrift, nr 4: 489-501.

Widén, Johan (1926) „Den nya barnavårdslagens syftemål och medlen för dess ernående»i Tid- 
skrift för barnavård och ungdomsskydd, $\mathrm{nr} \mathrm{l}$.

Åberg, Ingrid(1988) „Revivalism, Philanthropy and

Emancipation. Women«s liberation and Organization in the Early Nineteenth Century" i Scandinavian Journal of History, vol 13: 399-420.
Åman, Anders (1976) Om den offentliga vården. Byggnader och verksamheter vid svenska vairdinstitutioner under 1800- och 1900-talen. En arkitekturhistorisk undersökning. Stockholm: Liber.

\section{Summary}

\section{Voluntary Social Work under Reconsideration}

The role of the voluntary sector is under reconsideration in Sweden. This is especially true in social service and social work, where its capacity as a service producer is emphasized more than before. In this article the history of the relations between state and voluntary sector as well as the conditions for an expansion of the voluntary sector within the social service field are discussed. The history of the relations between state and voluntary sector can be divided into six periods: 1) The breakthrough of charity from around 1820 to 1890 , which is characterized by the growth of charity organizations, but also by close cooperation between the charities and the local authorities within the municipalities. 2) Organized philanthropyfrom around 1890 to 1920 , which coincides with the breakthrough of an early Swedish social policy discourse, can be described as the peak for organized charity. This period is also characterized by cooperation and close links between philanthropy and state. The integrative processes between the voluntary and state sector are in other words deepened. 3) Stagnation from around 1920 to 1940, when the importance of charity as an avant garde in social services is reduced. 4) The period of "taking over", fromaround 1945 to 1960 , coincides with the growth of the Swedish welfare state and means that the state sector takes over some activities within the social service field. The "take-overs" were motivated by the need for modernization or the need to make the activities part of the instititutionalized welfare system. 5) Organization from below, from around 1960 to 1980 , when the voluntary sector demonstrated its ability to organize groups such as clients and the handicapped. 6) Changed conditions, from the 1980s onwards. Even in an institutionalized welfare state like Sweden, voluntary organizations still have an important role today in the social field, both as organizers of interests and as producers of services. Because of altered economic and ideologic conditions, including strain on state budget, the pressure on voluntary organizations might however increase. This may lead to an expanded role in service production and a reduced role in ideology production and as moulders of interest. The voluntary organizations and the municipalities have not developed strategies to cope with these changed conditions. 